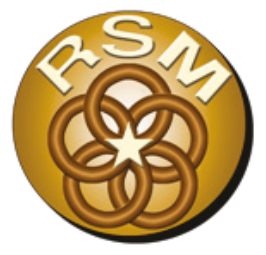

\title{
Alternatives to Manage Sediment at the Intersection of the Gulf Intracoastal Waterway (GIWW) and the Corpus Christi Ship Channel (CCSC)
}

\author{
by Paul Hamilton, Eric Wood, Lihwa Lin, Tricia Campbell, \\ Leslie Olson, Seth Jones, Steven Howard, and Kathy Skalbeck
}

PURPOSE: The purposes of this U.S. Army Corps of Engineers (USACE) Regional Sediment Management Technical Note (RSM-TN) are to document the development of alternative approaches to managing sediment at the intersection of the Gulf Intracoastal Waterway (GIWW) and the Corpus Christi Ship Channel (CCSC), Texas, and to determine the relative benefits and risks of each alternative. These alternatives potentially enhance navigation at this specific location but also enhance general understanding of navigable channel interactions in similar circumstances. The purpose of this study was to provide potential alternatives to managing the sediment at these locations. Sediment budget is discussed for readers to understand the magnitude of the channel shoaling situation in Corpus Christi Bay. The study area is shown in Figure 1.

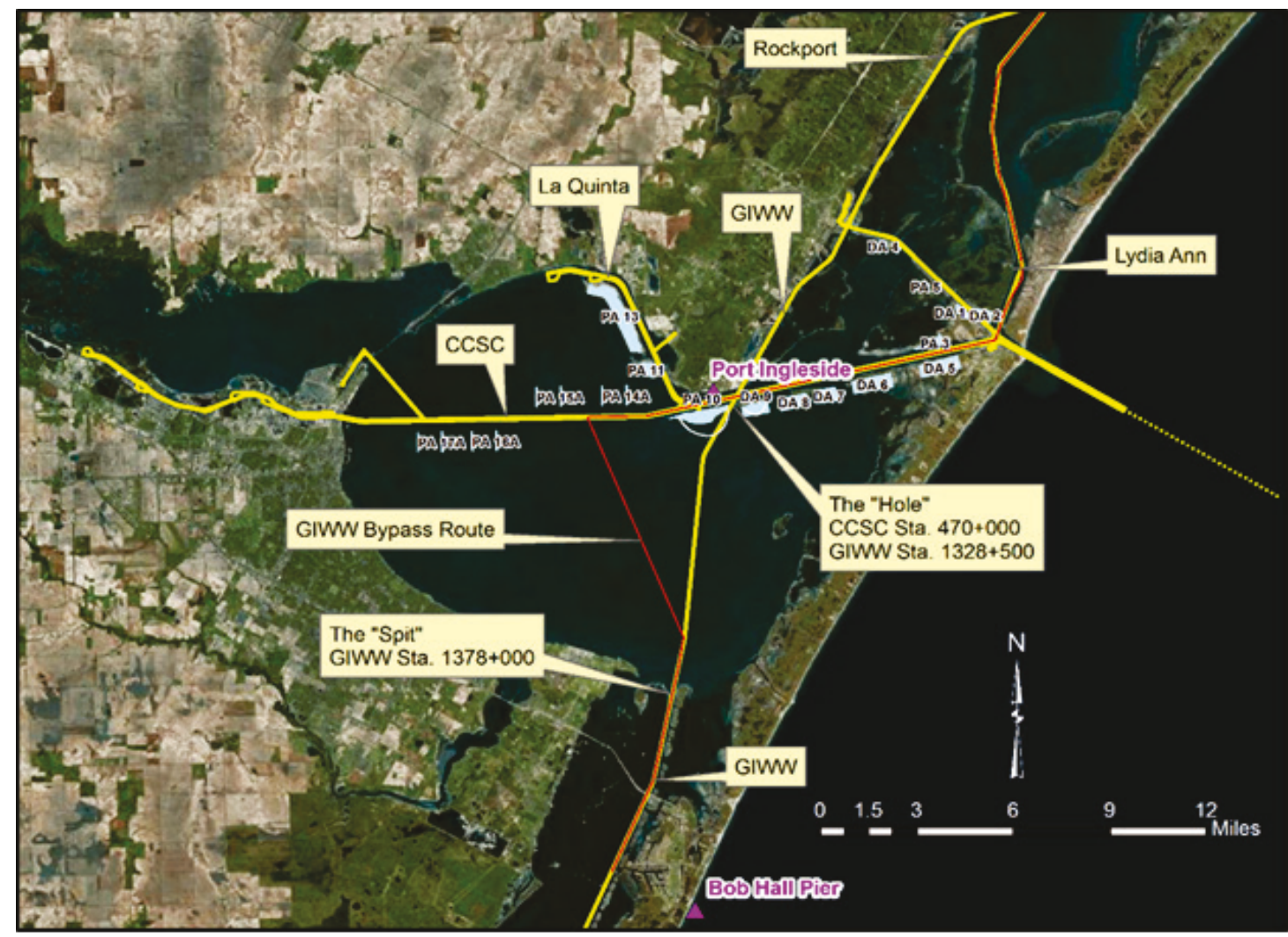

Figure 1. Overview of the study area, showing the intersection of the (GIWW) and the CCSC, Texas, and locations of the "Hole" and the "Spit" shoaling areas in Corpus Christi Bay. 
INTRODUCTION: This Regional Sediment Management (RSM) project addresses navigation issues along the GIWW in the vicinity of the CCSC. Channel shoaling has been a significant issue in the area over the last several years and has thereby jeopardized the navigability of the GIWW. Delays occur because pilots must leave the federal channel to navigate around two major shoaling areas in the GIWW: (1) the GIWW approximately between Station (Sta.) 1324+000 and Sta. 1333+000, near where the GIWW intersects the CCSC at CCSC Sta. 470+000, referred to as the "Hole," and (2) the GIWW approximately between Sta. 1371+000 and Sta. 1385+000, referred to as the "Spit." This study focuses primarily on the shoaling conditions in the Hole area.

HISTORICAL DATA: The CCSC is a 47-foot (ft) deep Mean Lower Low Water (MLLW) channel that extends from the Gulf of Mexico to the Port of Corpus Christi through Corpus Christi Bay (Figure 1). The CCSC intersects the GIWW, an approximately 14-ft deep MLLW channel, near CCSC Sta. 470+000. The CCSC is a high-traffic navigation corridor that requires continuous maintenance dredging. The channel shoaling issues reviewed as a part of this project occur in the GIWW. Historical aerial photographs of the Hole and Spit locations are shown in Figure 2 and Figure 3, respectively. The opening known as the Hole was once a single landmass that intersected what is now the GIWW at this location (Figure 2A). After the GIWW was initially dredged, the land mass to the west of the GIWW became two conjoined Placement Areas - PA 10 for the CCSC on the western half of the land mass and PA 164 for the GIWW on the eastern half (Figure 2D). The time series of aerial imagery shown in Figures 2A-2D indicates the island evolution as the land masses continue to encroach on the GIWW.

Most pilots, except those of small boats and tugs, utilize the Lydia Ann Channel (Figure 1) to bypass the GIWW between Rockport and the main channel of the CCSC at the Hole, near Port Ingleside. The Hole is bypassed by a route going west through Corpus Christi Bay along the CCSC. This route runs west along the CCSC, west of the GIWW connection to the CCSC (west of the Hole). The bypassing route is highlighted in red in Figure 1, and the channel is marked since it is used so frequently. The United States Coast Guard investigated the Hole in early 2016 and found it was mostly closed off and dangerous to navigation. Multiple sandbars and shallow water make the Hole impassable for all ships except small pleasure craft and some barges with light loads.
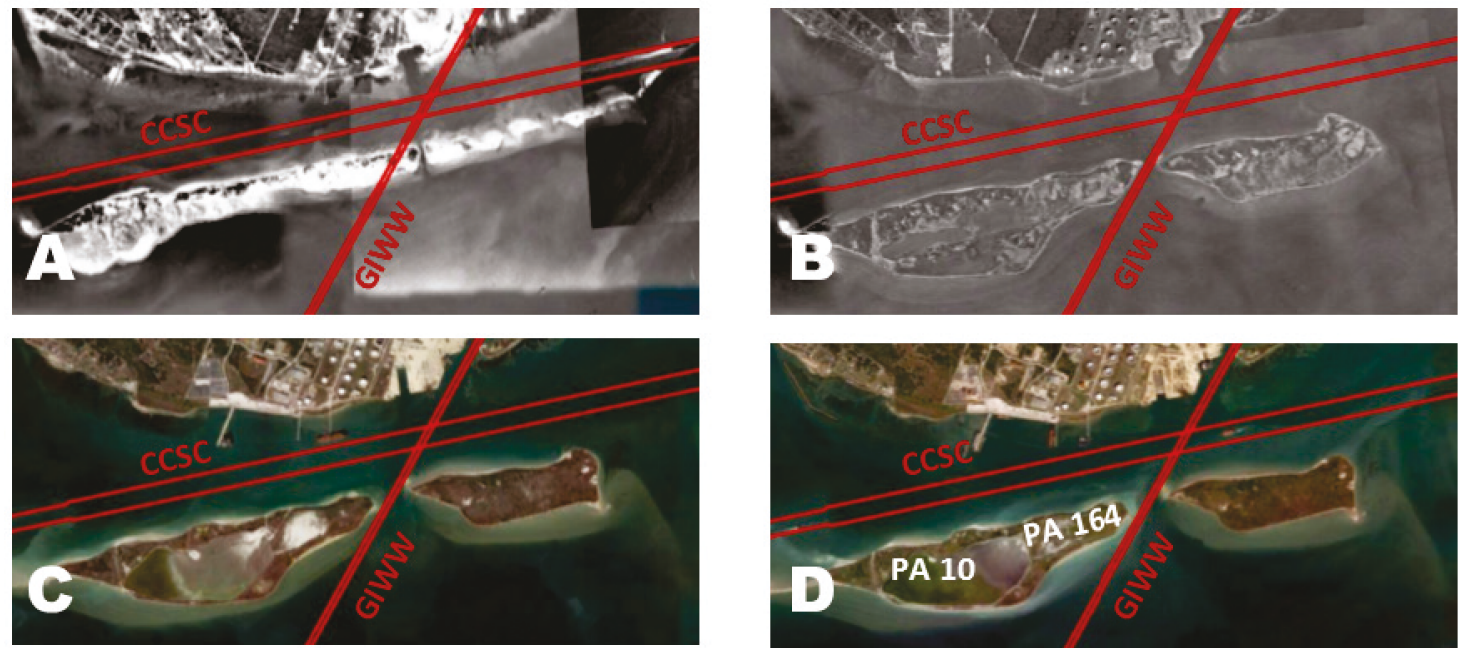

Figure 2. Historical aerial photographs of the Hole: (A) 1979, (B) 1985, (C) 2011, and (D) 2015. 

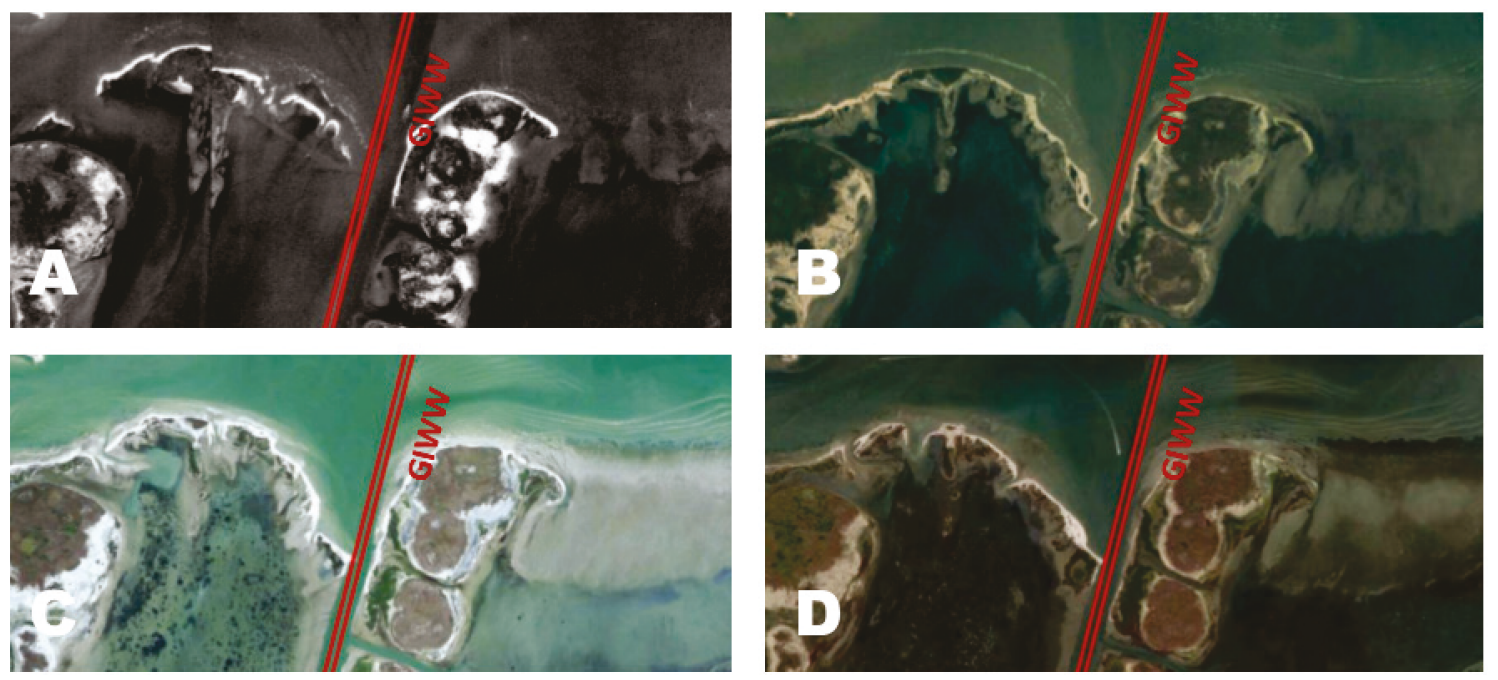

Figure 3. Historical aerial photographs of the Spit: (A) 1979, (B) 2003, (C) 2009, and (D) 2012.

The other region of interest, the Spit (Figure 3), is located along the southern edge of Corpus Christi Bay. The navigation issues at the Spit are not as dire as at the Hole. Pilots navigate the area through the Spit although this region of the GIWW requires frequent dredging, on the order of every 2 years, to maintain navigability.

The navigation issues in the area are reflected in data collected on historical waterway traffic (vessel type, draft, beam, length transit time, speed over ground, and direction) via the Automatic Identification System (AIS) (https://www.navcen.uscg.gov/) and application of the Automatic Identification System Analysis Package (AISAP), a tool that allows unprecedented access to quantitative, statistically robust measures of navigation project performance through time as reflected in vessel records (AISAP 2016). Traffic data at the Hole during March 2016 indicated that a total of 10 vessels transited that section of the GIWW a total of 21 times. Traffic for the same time period at the Spit was 60 transits by 20 distinct vessels. A heat map reflecting vessel traffic for the March 2016 period of analysis for the GIWW-CCSC region is shown in Figure 4. Heavy traffic is represented in yellow and pink.

HISTORICAL DREDGING DATA: The USACE Dredging Information System database was used to better understand dredging operations in the study area. The CCSC has been routinely dredged. The GIWW is dredged less frequently between Rockport and the CCSC. The GIWW near the Hole has not been dredged since 1994. Farther south near the Spit, the GIWW is regularly dredged; however, there are often draft issues. Figure 5 shows the cumulative volume dredged from the GIWW near the Spit (Sta. 1368+000 to Sta.1389+000) since 1950. Averaging over this spatial and temporal window gives an average removal rate of 54,500 cubic yards per year (cy/year) or the equivalent of approximately $0.64 \mathrm{ft} /$ year. 
ERDC/TN RSM-18-10

November 2018

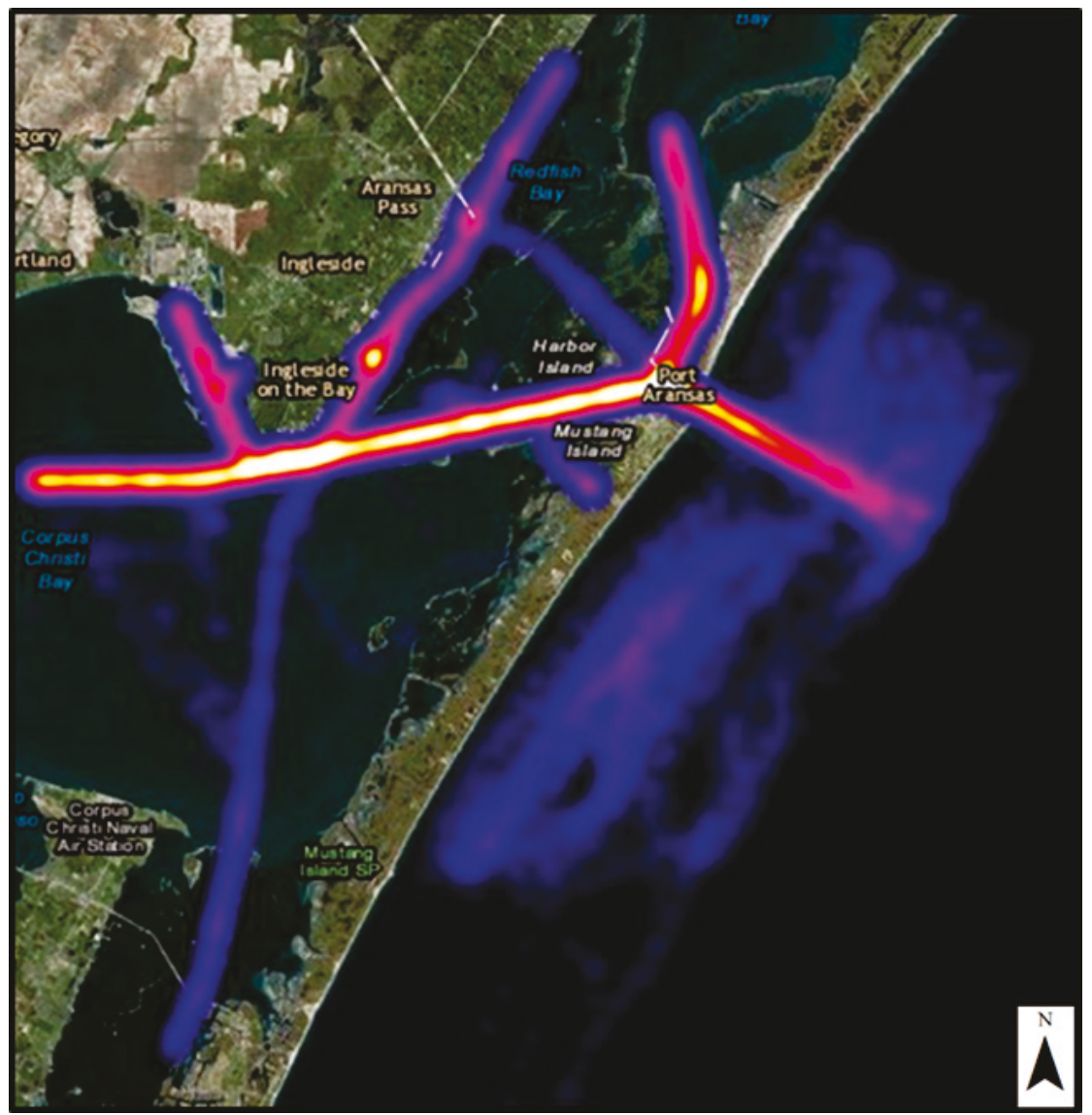

Figure 4. AIS data for March 2016 for the GIWW - CCSC region.

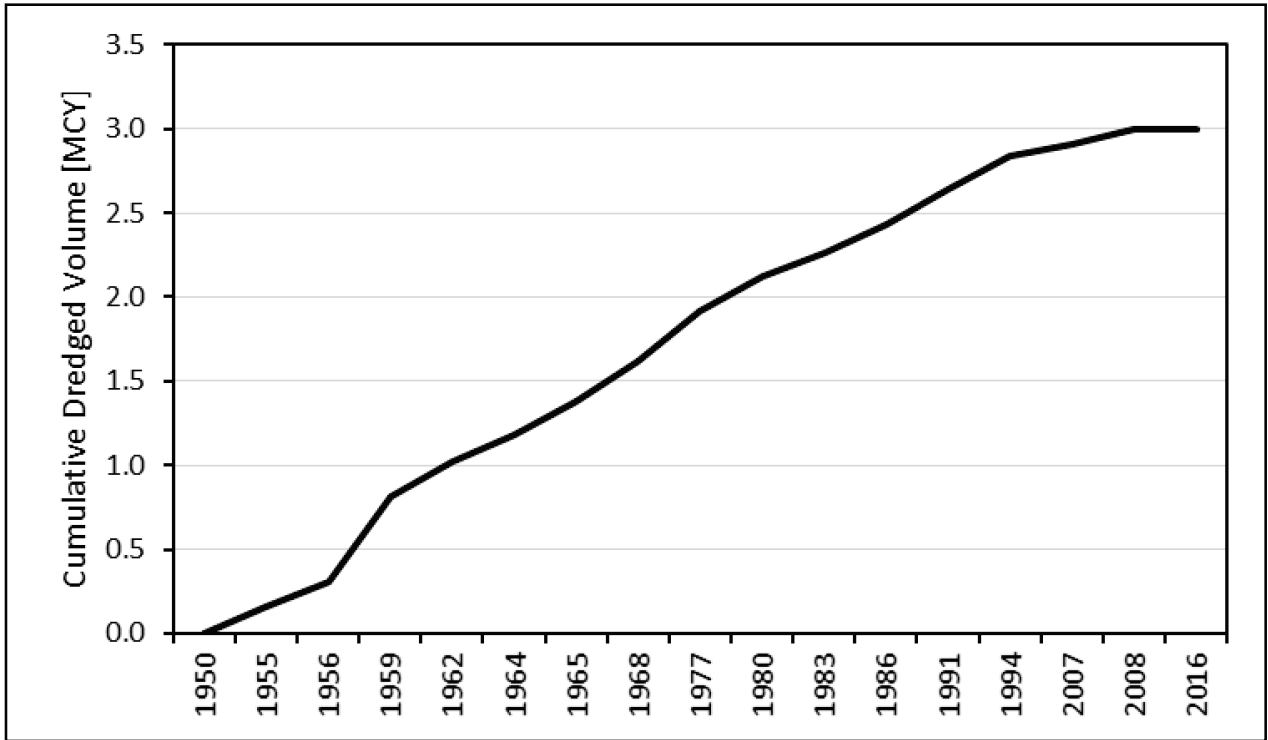

Figure 5. Cumulative volume dredged from the GIWW near the Spit (GIWW Sta. $1368+000$ to Sta. $1389+000)$ since 1950. 
DATUM INFORMATION: Water level vertical datum data are listed in Table 1 for two stations near the project area, Station ID 8775283 near Port Ingleside and Station ID 8775870 near Bob Hall Pier.

Table 1. Vertical datum (feet) information in the vicinity of the project site.

\begin{tabular}{|l|l|c|c||}
\hline \hline Datum & Description & $\begin{array}{c}\mathbf{8 7 7 5 2 8 3} \\
\text { Port Ingleside }\end{array}$ & $\begin{array}{c}\mathbf{8 7 7 5 8 7 0} \\
\text { Bob Hall Pier }\end{array}$ \\
\hline \hline MHHW & Mean Higher-High Water & 3.40 & 22.47 \\
\hline MHW & Mean High Water & 3.39 & 22.38 \\
\hline MTL & Mean Tide Level & 3.11 & 21.72 \\
\hline MSL & Mean Sea Level & 3.14 & 21.77 \\
\hline MLW & Mean Low Water & 2.82 & 21.07 \\
\hline MLLW & Mean Lower-Low Water & 2.81 & 20.84 \\
\hline
\end{tabular}

THE HOLE eHYDRO/CSAT ANALYSES: Hydrographic survey data collected between 2012 and 2015 were used for two purposes: (1) to update the bathymetry used in numerical modeling (discussed in the following section) and (2) to populate survey databases using the enterprise hydrographic survey application, eHydro (Littell and Gavin 2015). This bathymetry and these databases were used to calculate sediment accumulation rates with the U.S. Army Engineer Research and Development Center (ERDC) Corps Shoaling Analysis Tool (CSAT) (Dunkin and Mitchell 2015). The CSAT compared the amalgamated survey data and when combined with dredging information, determined sediment accumulation in the GIWW and furthermore revealed shoaling hot spots. The CSAT output for the GIWW is listed in Table 2.

Table 2. CSAT results for the GIWW reaches near the CCSC.

\begin{tabular}{||l||c|c|c|c||c|c|c||}
\hline \hline \multirow{2}{*}{$\begin{array}{l}\text { Reach ID, GIWW } \\
\text { Station Range }\end{array}$} & \multirow{2}{*}{$\begin{array}{l}\text { Surveys } \\
\text { Per Year }\end{array}$} & \multicolumn{2}{|c|}{ Shoaling Rate (ft/year) } & \multicolumn{2}{|c|}{ Shoaling Volume (cy/year) } \\
\cline { 5 - 9 } & & Avg. & Max. & Min. & Avg. & Max. & Min. \\
\hline $\begin{array}{l}\text { Corpus Christi Bay } \\
\text { To Aransas Bay, } \\
1236+611-1326+000\end{array}$ & 1.51 & 0.96 & 1.84 & 0.08 & 59,563 & 113,737 & 5,259 \\
\hline $\begin{array}{l}\text { Across Corpus } \\
\text { Christi Bay, } \\
1326+000-1369+000\end{array}$ & 1.29 & 0.23 & 0.53 & -0.10 & 46,626 & 106,326 & $(20,831)$ \\
\hline $\begin{array}{l}\text { Corpus Christi Bay } \\
\text { To Baffin Bay, } \\
1369+000-1459+000\end{array}$ & 1.42 & 1.04 & 1.87 & 0.51 & 433,729 & 775,973 & 211,107 \\
\hline
\end{tabular}

Figure 6 shows the raster output for the Hole. The average shoaling rate in the GIWW near the Hole was $0.73 \mathrm{ft} /$ year, averaged between Sta. 1326+500 and Sta. 1329+000. Note that these results were based on a limited number of surveys collected from 2012 through early 2016, and full survey coverage of the area was not available for a majority of the surveys. Therefore, the CSAT shoaling rates are only quantified for the portion of the focus area where hydrographic survey data 
exist. As such, these shoaling rates should be updated as additional surveys that cover the entire focus area become available. The additional surveys with coverage over the entire focus area will provide more data and comparisons to accurately quantify the shoaling rates.

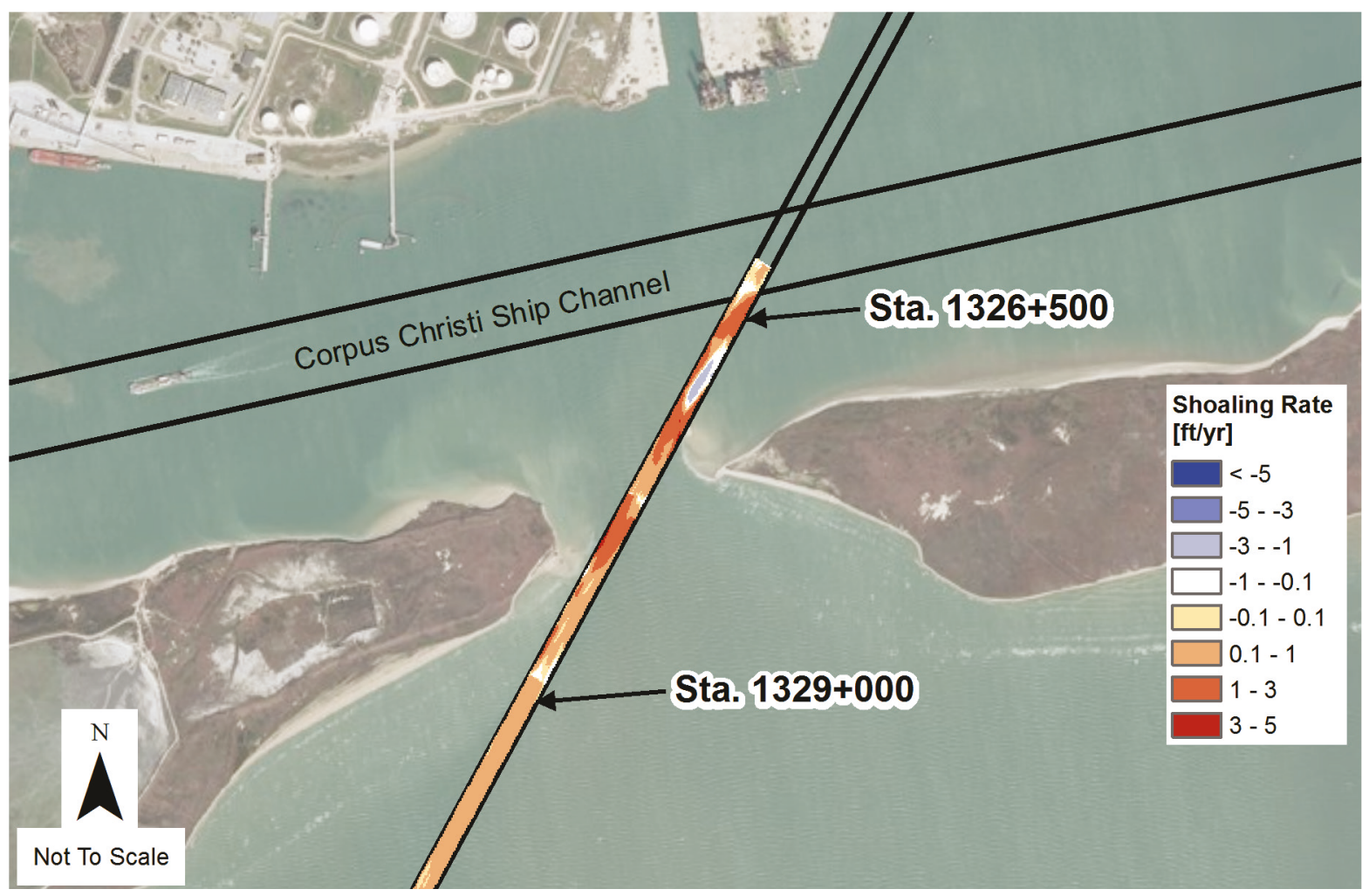

Figure 6. CSAT results for the Hole. Average shoaling rate was $0.73 \mathrm{ft} / \mathrm{year}$, averaged between GIWW Sta. $1326+500$ and Sta. $1329+000$.

THE HOLE NUMERICAL MODELING: The physical processes in the study area were simulated using the ERDC Coastal Modeling System (CMS) (Demirbilek and Rosati 2011). For this study the CMS was used to (1) establish existing conditions and (2) analyze the effectiveness of potential alternatives relative to the existing condition (i.e., do-nothing condition). The CMS domain in and around Corpus Christi Bay was a modification of that used by Reed and Lin (2011) to investigate the Packery Channel associated with Corpus Christi Bay. The CMS grid covers a 32.3 mile by 41.0 mile area divided into cells that ranged in size from $40 \mathrm{ft}$ by $40 \mathrm{ft}$ up to $985 \mathrm{ft}$ by $985 \mathrm{ft}$ in water depths up to $60 \mathrm{ft}$ (Figure 7). 


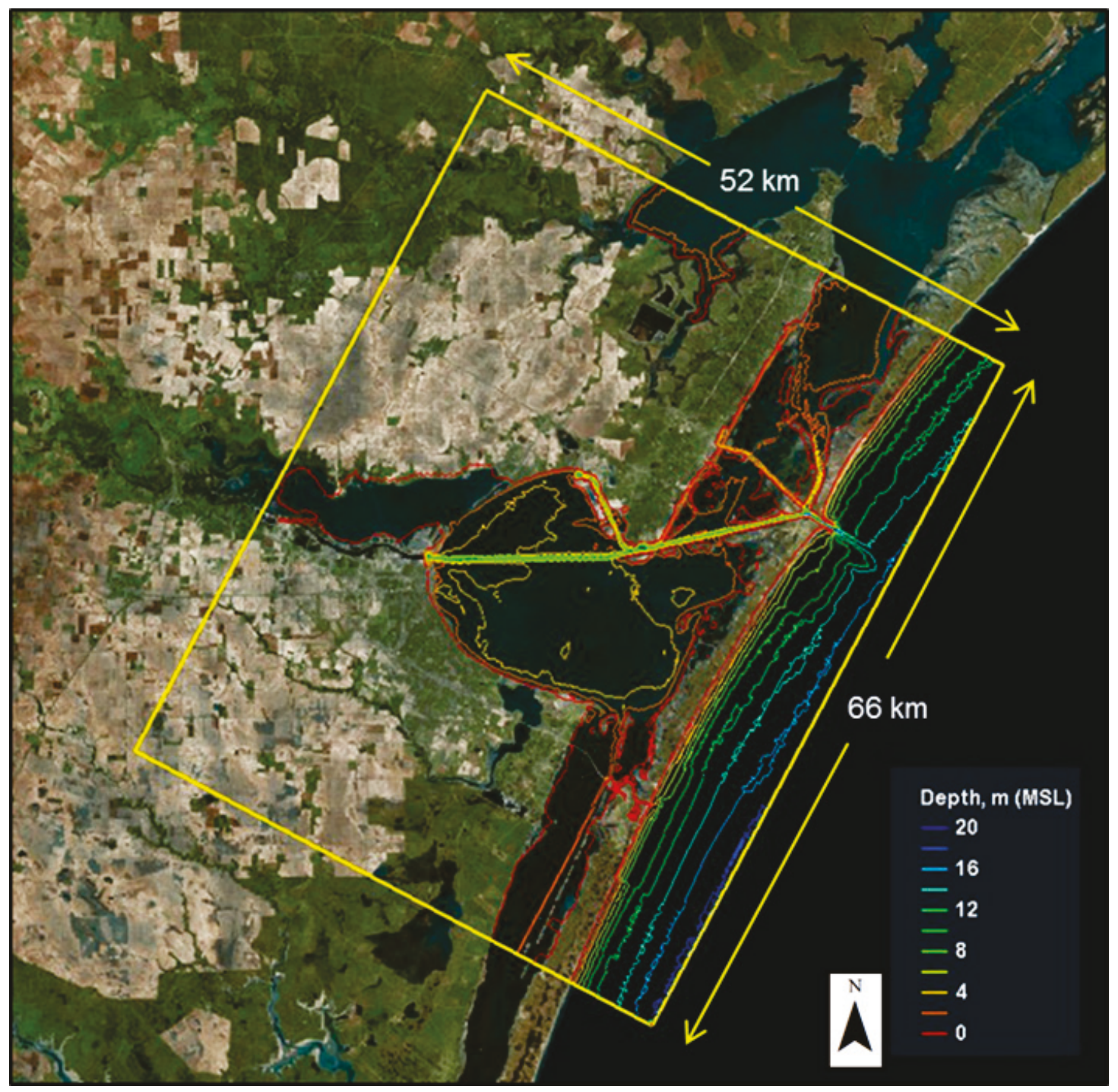

Figure 7. CMS domain.

Model calibration of hydrodynamics in the Corpus Christi Bay was performed with field water level data for February 2016. Water-level forcing was based on data from the National Oceanic and Atmospheric Administration (NOAA) coastal stations at (1) South Bird Island (ID 8776139), (2) Rockport (ID 8774770), and (3) Bob Hall Pier (ID 8775870). Coastal wind and wave forcing was based on data from the NOAA National Data Buoy Center Buoy Number 42020. Figure 8 compares the calculated water levels and data at NOAA station USS Lexington (ID 8775296), Corpus Christi Harbor. Because there were no current or wave measurements in Corpus Christi Bay, the CMS model calibration with current and wave data was based on a previous study of the neighboring Matagorda Bay for 1 January through 28 February 2014 (Rosati et al. 2011; Lambert et al. 2013). For sediment transport, the model applied the same method used and documented in three previous modeling studies (Lambert et al. 2013; Lin and Reed 2015; Wood et al. 2017). 


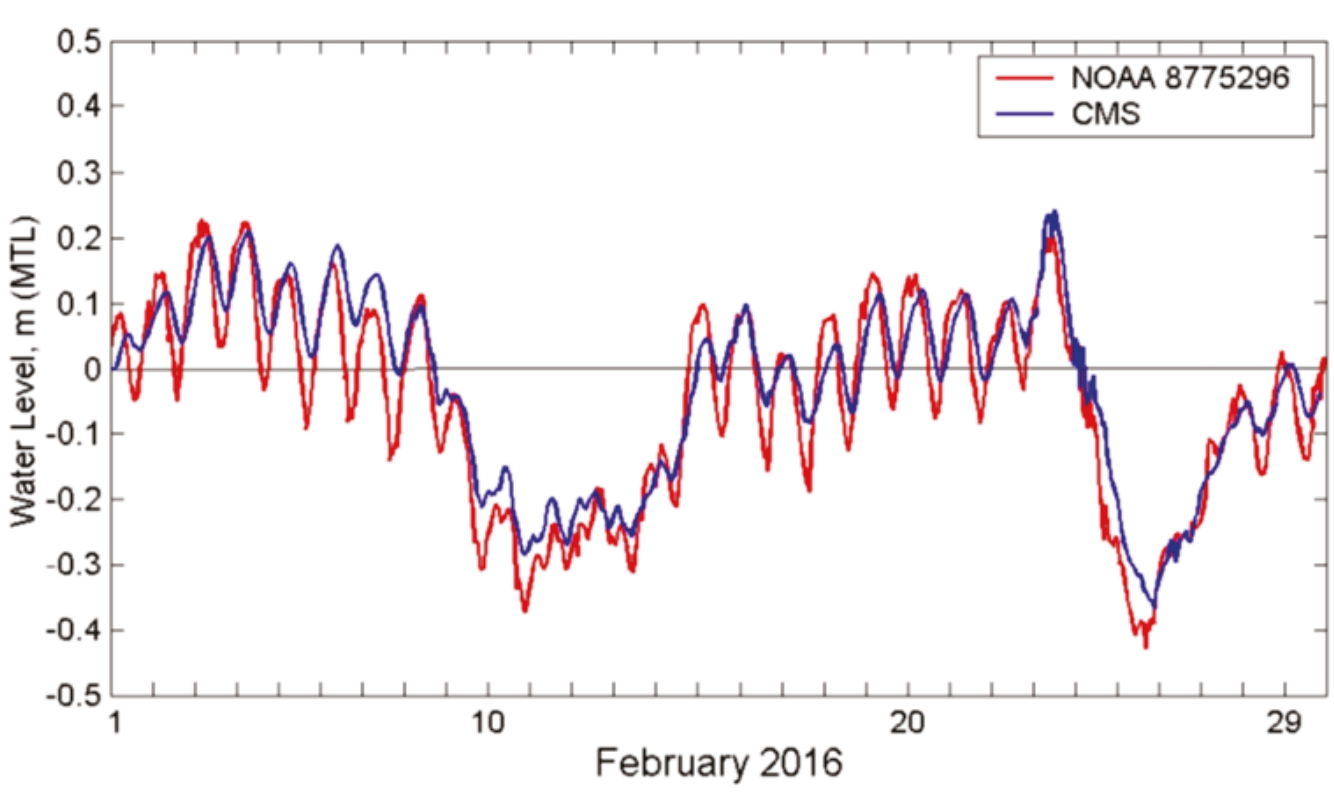

Figure 8. Comparison of calculated and measured water levels at NOAA station USS Lexington (ID 8775296), Corpus Christi Harbor, February 2016.

The simulations were run for the 6-month period spanning November 2015 - April 2016. This period is characteristic of typical and recent environmental conditions (e.g., moderate wind, tide, and wave forcing, and absence of a significant tropical event). An example of the calculated velocity field is shown in Figure 9. Figure 10 shows the calculated morphology change over the 6-month period. The annual accretion/erosion range for the Hole area is approximately $+/-3.3 \mathrm{ft}$. Because the bay is quite calm during the summer, most channel shoaling occurred from the late fall to early spring with stronger northeasterly wind. The associated calculated accretion volume is approximately 30,000 cy/year, which is within the range of channel shoaling rates observed in this section of the GIWW.

The HOLE SEDIMENT BUDGET ANALYSIS: The ERDC Sediment Budget Analysis System (SBAS) (Rosati and Kraus 1999; Dopsovic et al. 2003) was used in the study area (Figure 11) to characterize sediment gains, losses, and fluxes from natural processes and from dredging removal and placement. Historical dredging information was used to determine removal from discretized reaches of the CCSC and GIWW. Absent specific information regarding dredged material placement, dredged material volumes were assumed to be placed in a nearby placement area or were divided among placement areas in the case of ambiguity. SBAS has built-in confidence bins based on certainty of the inputs. High confidence was used for the removal values given their basis in historical data, and Medium confidence was used for the placement values given some ambiguity of particular placement area used. The exchange between cells (i.e., flux rates) were informed by the eHydro/CSAT results regarding shoaling rates and by the CMS modeling regarding transport direction. As a final note, the sediment budget is not volumetric over a defined time period but rather an annualized volumetric rate over the period of available historical data. 


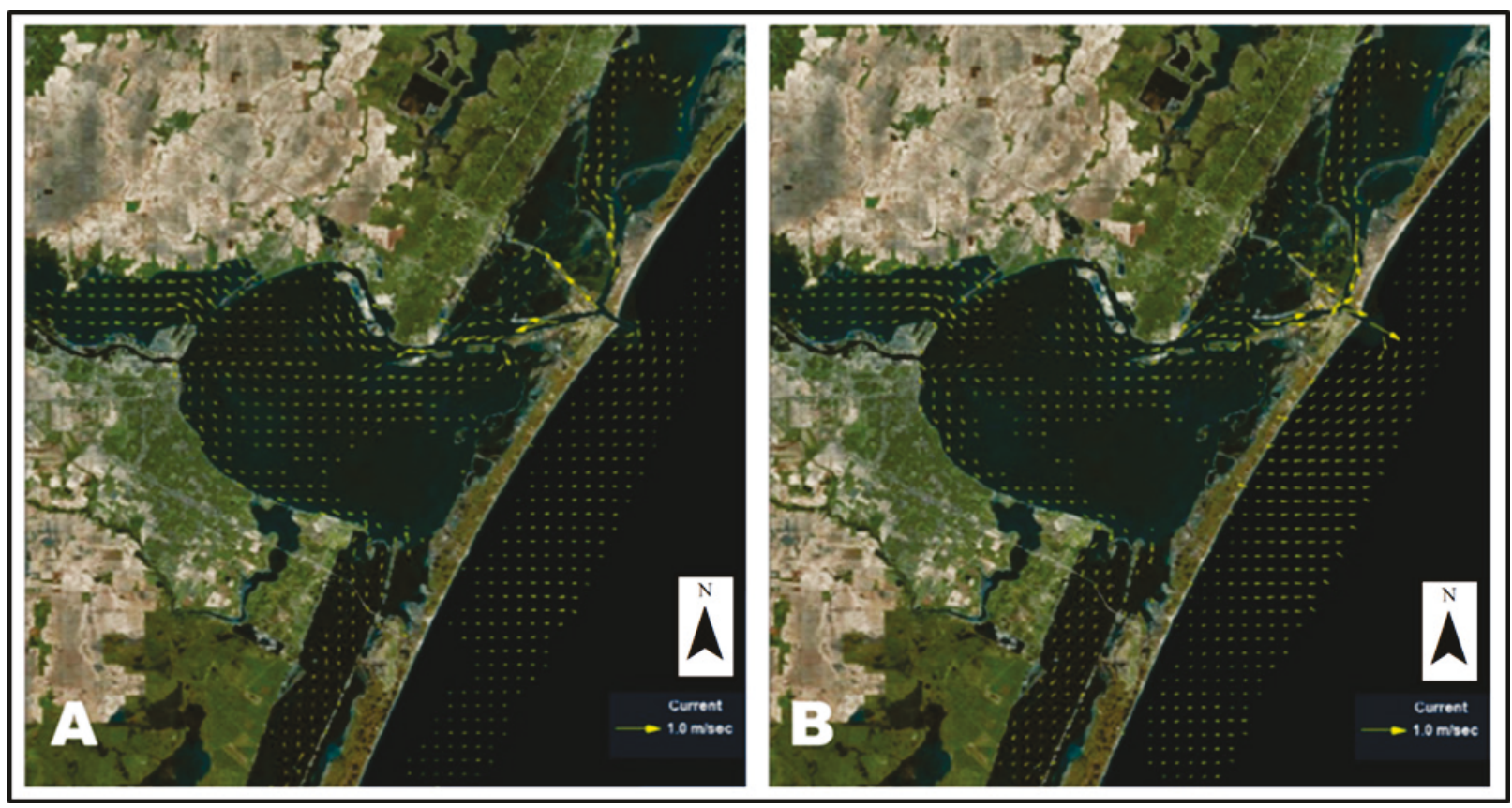

Figure 9. Velocity fields from CMS simulation for (A) maximum flood current (2200 GMT, 14 February 2016) and (B) maximum ebb current (1700 GMT, 24 February 2016).

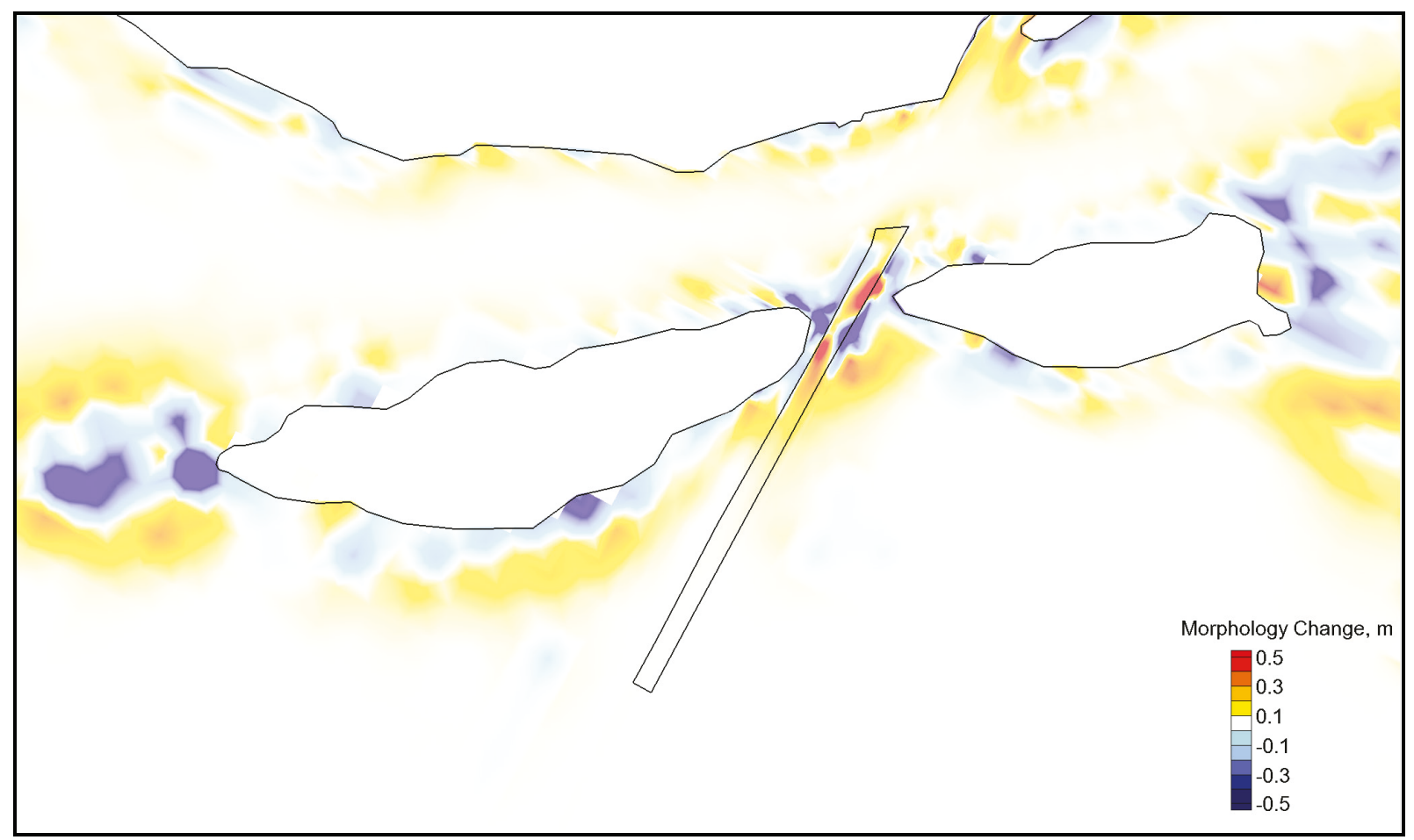

Figure 10. Calculated morphology change over the 6-month simulation period, November 2015 - April 2016, in the vicinity of the Hole. 


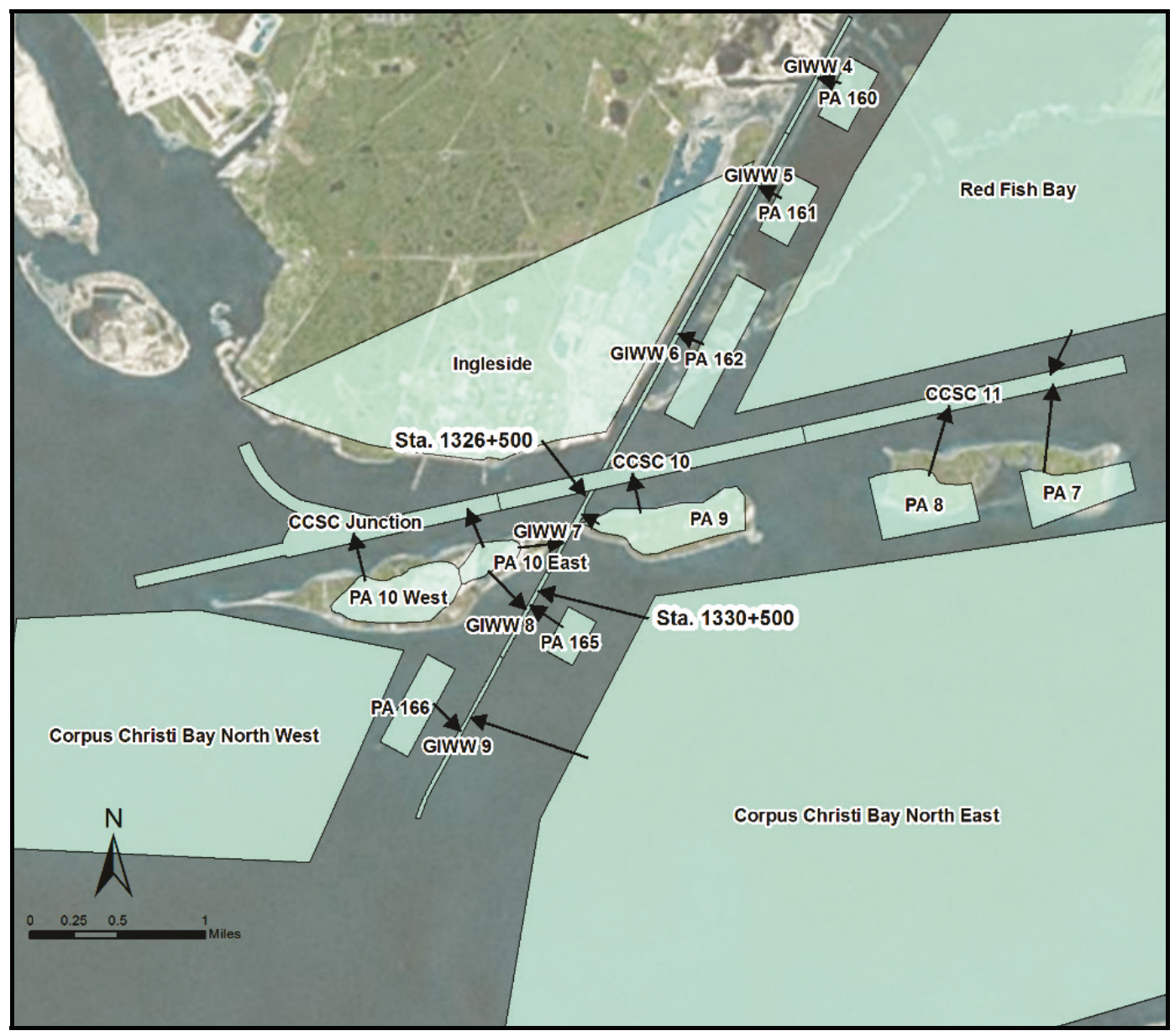

Figure 11. SBAS sediment budget cells and fluxes near the Hole. (Arrows without station locations indicate flux lines connecting those respective cells.)

In the case of the Hole, since dredging operations are not active, the results are slightly nebulous. The depressions imposed by dredging would accumulate sediment more quickly than areas with elevations more similar to adjacent bathymetry. This, of course, is also predicated on no structural measures that would otherwise impede sediment transport.

THE HOLE ALTERNATIVE ANALYSES: Four alternatives were considered to mitigate the shoaling issue at the Hole and were analyzed using the CMS models to determine their respective effectiveness relative to existing conditions. Alternatives $1-3$ alter the geometry of the GIWW while Alternative 4 includes walls constructed along both sides of the GIWW.

Alternative 1. Deepen the GIWW at the Hole. Alternative 1 attempts to address high deposition rates in the GIWW at the Hole via increased advanced maintenance dredging. The measure is proposed for the 4,000 ft between Sta. $1326+500$ and Sta. $1330+500$. The width would be maintained at $125 \mathrm{ft}$ with an additional $2 \mathrm{ft}$ depth in the GIWW template, making the total depth $-19 \mathrm{ft}$ MLLW.

Alternative 2. Widen the GIWW at the Hole. This measure would widen the GIWW template at the Hole from 125 to $200 \mathrm{ft}$ between Sta. 1326+500 and Sta. 1328+500. The dredged 
depth would remain at $-17 \mathrm{ft}$ MLLW. This measure has the benefit of more aggressively removing sediment accumulation due to the accreting landforms.

Alternative 3. Shallow the GIWW Side Slope at the Hole. Like the previously discussed alternatives, this measure would alter the GIWW template at the Hole. Alternative 3 would modify the side slopes from $3 \mathrm{H}: 1 \mathrm{~V}$ to $4 \mathrm{H}: 1 \mathrm{~V}$ and would maintain channel depth at $-17 \mathrm{ft}$ MLLW and width at $125 \mathrm{ft}$. This measure would be applied between Sta. 1326+700 and Sta. 1328+700.

Alternative 4. Structural Measures along Both Sides of the GIWW at the Hole. This measure represents the only structural option considered and would consist of walls constructed on either side of the GIWW to suppress sediment accumulation in the navigable channel. The east wall would run alongside the channel between Sta. $1326+800$ and Sta. $1328+200$. The west wall would consist of two connected segments: the first between Sta. 1327+800 and Sta. $1328+000$ and the second between Sta. $1328+000$ and Sta. $1328+350$. For both cases, the wall would extend above MLLW by 2.3 to $3.3 \mathrm{ft}$ to block wakes generated by passing ships.

\section{THE HOLE SUMMARY OF MODELING RESULTS AND ALTERNATIVE SELECTION:}

The relative sediment accumulation associated with each alternative over the analysis period is listed in Table 3. The sediment accumulation calculation is based on model calibration with fine sand and silty material. The sediment transport factors used in the model for both bed load and suspended load were 0.3. Modeling results indicate that geometric changes alone are not adequate for shoaling reduction in the area and that the Alternative 4 structural measures would be most effective. Although structural measures are most effective in reducing sediment accumulation, geometric alteration could make the area more maintainable. A future economic analysis would reveal the ideal choice for this area.

Table 3. CMS Sediment accumulation calculations, November 2015 through February 2016.

\begin{tabular}{|l|c|c||}
\hline \hline Alternative & Accumulation (cy) & Percent (\%) Reduction \\
\hline \hline 0 (Existing Conditions) & 29,750 & - \\
\hline 1 (Deepen GIWW) & 28,100 & 6 \\
\hline 2 (Widen GIWW) & 29,850 & 0 \\
\hline 3 (Lower GIWW Side Slopes) & 37,000 & 0 \\
\hline 4 (Structural Measures) & 18,500 & 38 \\
\hline
\end{tabular}

THE SPIT eHYDRO/CSAT ANALYSES. The utility of the eHydro database and CSAT analysis was discussed in a prior section. The regional results for the GIWW are provided in Table 2. For the GIWW in the vicinity of the Spit between Sta. 1378+000 and Sta. 1380+000, the average accumulation rate is $0.87 \mathrm{ft} /$ year. As with the Hole, this singular value can be misleading given that average accumulation near the eastwardly accreting Spit is approximately $3.0 \mathrm{ft} / \mathrm{year}$. The rasterized results are shown in Figure 12. 


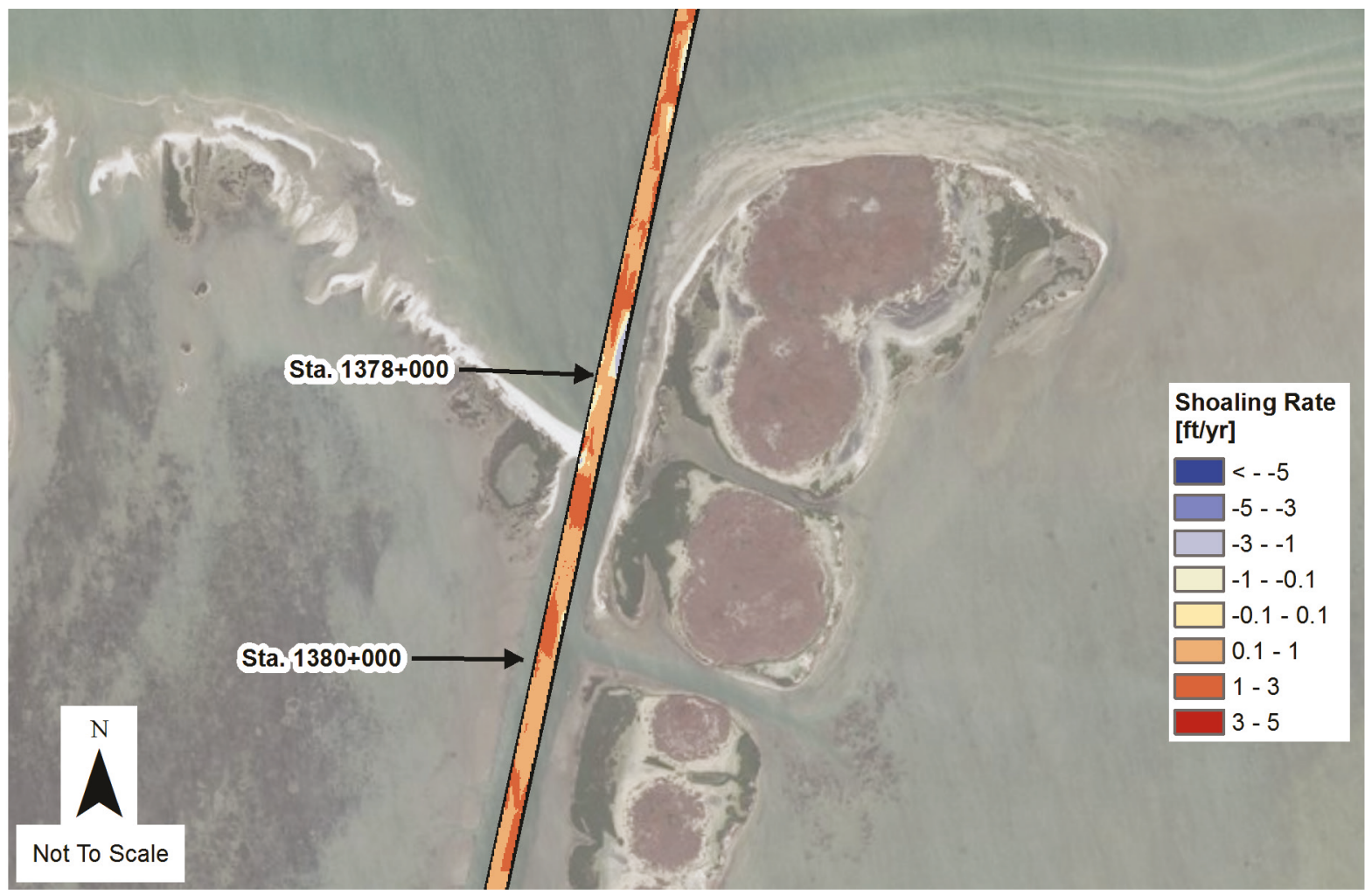

Figure 12. CSAT results at the Spit. Average shoaling rate was $0.87 \mathrm{ft} /$ year between GIWW Sta. $1378+000$ and Sta. $1380+000$ (shoaling in red, positive; erosion in blue, negative).

THE SPIT SEDIMENT BUDGET ANALYSIS: The same sediment budget approach as discussed at the Hole was used at the Spit. The littoral cells and fluxes for the sediment budget are shown in Figure 13. The bathymetric low imposed by maintenance dredging creates higher trapping efficiency of intersecting sediment transport. CMS simulations show currents that alternate in direction with the ebb/flood tide but are in both cases approximately perpendicular to the GIWW (Figure 9). This is true both north of the Spit where the GIWW is adjacent to the open water of Corpus Christi Bay and south of the Spit where the GIWW is bounded by tidally dissected subaerial land. These areas appear to account for approximately $40 \%$ of the sediment input into the stretch of the GIWW between Sta. $1375+000$ and Sta. 1389+000. Historical aerial photographs indicate that the shoreline on either side of the GIWW south of the Spit has been relatively stable. While the Spit itself is an impediment to navigation as it impinges on the GIWW, it is not necessarily a major source of sediment for the entire reach, although it is significant locally. 


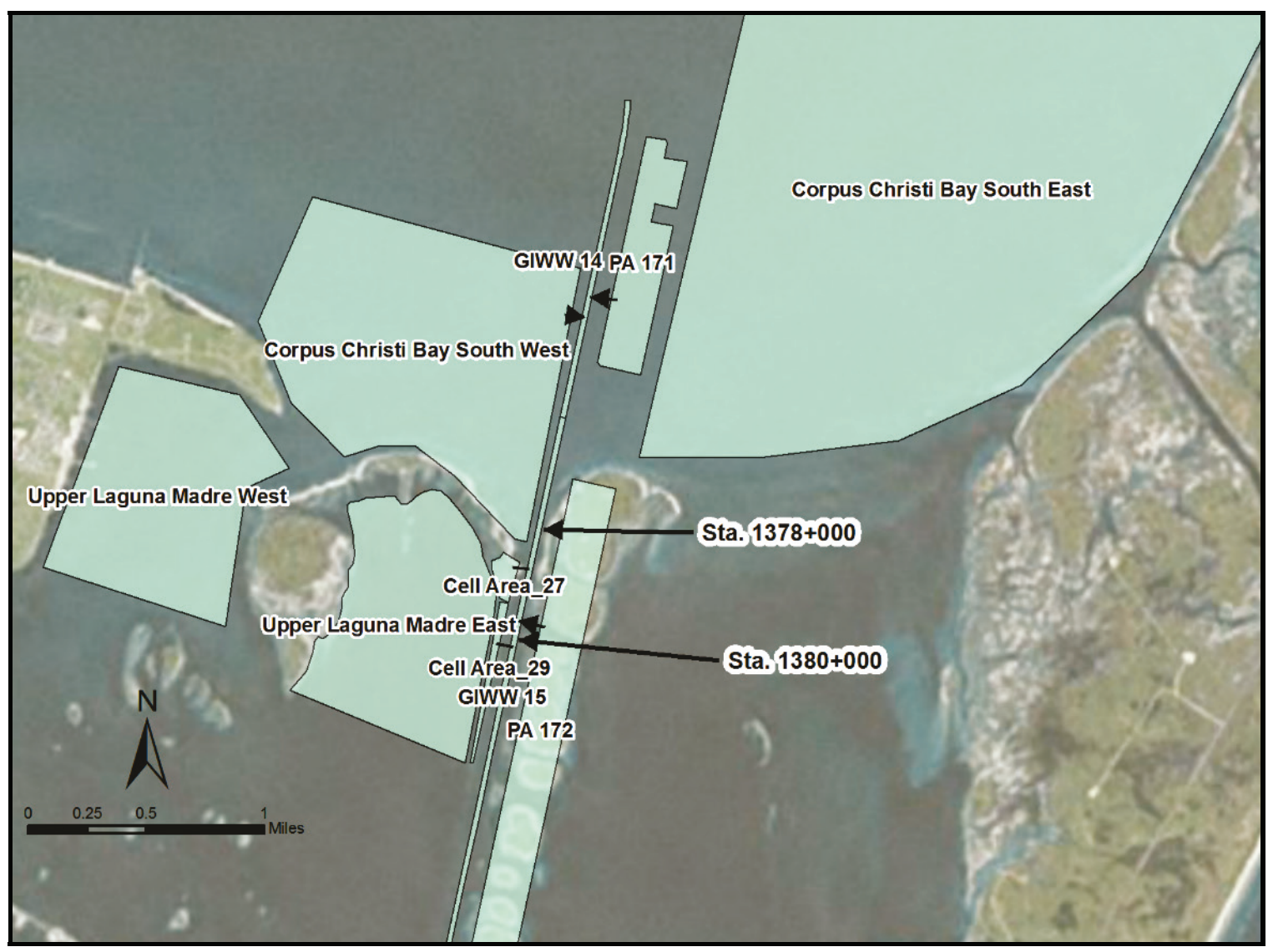

Figure 13. SBAS sediment budget cells and fluxes near the Spit.

THE SPIT ALTERNATIVE ANALYSES: Potential alternative solutions to address issues at the Spit were not modeled but are discussed here. This is an additional area of concern identified after the onset of the project. As with the Hole, the primary problem is landform accretion. One alternative is to mechanically remove the accretionary point back toward the west and relocate the sediment. The sediment could be relocated across the GIWW to the islands on the opposite side. This has the benefit of keeping the sediment in the system, although the southeastern island should perhaps be disqualified given the potential that a placement would disturb seagrass. Alterations to the GIWW template, similar to those discussed at the Hole, are a potential solution at the Spit. However, as previously noted, the underlying issue is landform accretion for which geometric alteration of the GIWW may not be a viable option, as shown in the modeling of the Hole. There is also potentially a structural alternative similar to the wall considered at the Hole that would restrain accretion and encroachment toward the GIWW.

CONCLUSIONS: The fundamental issue in each of the specific locations discussed goes beyond sediment accumulation and is rooted in landform accretion. Numerical modeling of potential alternatives at the Hole indicates that structural measures at that location would be more effective than altering the GIWW template for reducing shoaling in the area. Circumstances at the Spit are similar to that at the Hole. Therefore, the potential solution may be similar. These alternatives, and an associated economic analysis, should be pursued and studied further as a means for reducing shoaling in the study area. 
ERDC/TN RSM-18-10

November 2018

ADDITIONAL INFORMATION: This Regional Sediment Management Technical Note (RSMTN) was prepared by Paul Hamilton, Eric Wood, Tricia Campbell, Leslie Olson, Seth Jones, and Steven Howard, U.S. Army Engineer District, Galveston (SWG); Kathy Skalbeck, U.S. Army Engineer District, Fort Worth (SWF); and Lihwa Lin, U.S. Army Engineer Research and Development Center (ERDC), Coastal and Hydraulics Laboratory (CHL). Funding for this study was provided by the USACE National Regional Sediment Management (RSM) Program, a Navigation Research, Development, and Technology (RD\&T) portfolio program administered by Headquarters (HQ) USACE. Additional information pertaining to the RSM Program may be found at http://rsm.usace.army.mil. Questions regarding this CHETN may be addressed to Paul Hamilton, Paul.B.Hamilton@usace.army.mil. Questions pertaining to the RSM Program may be addressed to the USACE National RSM Program Manager, Linda Lillycrop, Linda.S.Lillycrop@usace.army.mil.

This USACE ERDC CHL Regional Sediment Management Technical Note (RSM-TN) should be cited as follows:

Hamilton, P., E. Wood, L. Lin, T. Campbell, L. Olson, S. Jones, S. Howard, and K. Skalbeck. 2018. Alternatives to Manage Sediment at the Intersection of the Gulf Intracoastal Waterway $(G I W W)$ and the Corpus Christi Ship Channel (CCSC). ERDC RSM-TN-18-10. Vicksburg, MS: U.S. Army Engineer Research and Development Center. http://dx.doi.org/10.21079/11681/30383

\section{REFERENCES}

Automatic Identification System Analysis Package (AISAP). 2016. Getting Started with AISAP. http://ais-portal.usace.army.mil/Getting\%20Started\%20With\%20AISAP.pdf

Demirbilek, Z., and J. D. Rosati. 2011. Verification and Validation of the Coastal Modeling System: Report 1; Summary Report. ERDC/CHL TR-11-10. Vicksburg, MS: U.S. Army Engineer Research and Development Center. http://acwc.sdp.sirsi.net/client/en_US/search/asset/1005704

Dopsovic, R., L. Hardegree, and J. D. Rosati. 2002 (rev 2003). Sediment Budget Analysis System-A: SBAS for Arcview Application. ERDC/CHL CHETN-XIV-7. Vicksburg, MS: U.S. Army Engineer Research and Development Center. http://acwc.sdp.sirsi.net/client/en_US/search/asset/1011264

Dunkin, L. M., and K. N. Mitchell. 2015. Quantitative approach to navigation channels asset management. In Proceedings of the Western Dredging Association and Texas A\&M University Center for Dredging Studies, Dredging Summit and Expo 2015. Houston, TX. https://www.researchgate.net/publication/289502865 QUANTITATIVE_APPROACH_TO NAVIGATION_CHANNELS_ASSET MANAGEMENT

Lambert S., S. Willey, T. Campbell, R. Thomas, H. Li, L. Lin, and T. Welp. 2013. Regional Sediment Management Studies of Matagorda Ship Channel and Matagorda Bay System, Texas. ERDC/CHL TR-13-10. Vicksburg, MS: U.S. Army Engineer Research and Development Center.

Lin, L., and C. W. Reed. 2015. Numerical modeling of mixed sediment transport in GIWW and West Galveston Bay, Texas. In Proceedings of Coastal Sediments 2015. San Diego, CA.

Littell, M., and W. S. Gavin. 2015. eHydro: Enterprise hydrosurvey processing within a GIS framework. In Proceedings of the U.S. Hydro 2015 Conference. National Harbor, MD. http://www.google.com/url? sa $=t \& r c t=j \& q=\& e s r c=s \&$ source $=w e b \& c d=1 \& v e d=0$ ahUKEwilqOeB5fTRAhXhq VQKHUarDLUQFggaMAA\&url=http $\% 3 \mathrm{~A} \% 2 \mathrm{~F} \% 2 \mathrm{Fwww}$.hypack.com\%2Fushydro\%2F $2015 \% 2 \mathrm{Fpapers} \% 2 \mathrm{Fpd}$ f\%2FM-Littell-US\%2520Hydro\%2520eHydro\%252020150317.pdf\&usg=AFOjCNHMXJUaRiqVftxVLo0i8DgaAsg $3 A$ 
Reed, C. W., and L. Lin. 2011. Analysis of Packery Channel public access boat ramp shoreline failure. Journal of Coastal Research Special Issue 59:150-155. http://dx.doi.org/10.2112/SI59-015.1

Rosati, J., A. E. Frey, M. E. Brown, and L. Lin. 2011. Analysis of Dredged Material Placement Alternatives for Bottleneck Removal, Matagorda Ship Channel, Texas. ERDC/CHL TR-11-2. Vicksburg, MS: U.S. Army Engineer Research and Development Center.

Rosati, J. D., and N. C. Kraus. 1999. Sediment Budget Analysis System (SBAS). CETN-IV-20. Vicksburg, MS: U.S. Army Engineer Research and Development Center. http://acwc.sdp.sirsi.net/client/search/asset/1000276

Wood, E., T. Campbell, M. Duke, L. Olson, L. Dunkin, and L. Lin. 2017. Identification of Alternatives to Reduce Shoaling in the Lower Matagorda Ship Channel. ERDC/TN RSM-17-1. Vicksburg, MS: U.S. Army Engineer Research and Development Center. http://dx.doi.org/10.21079/11681/22408

NOTE: The contents of this technical note are not to be used for advertising, publication, or promotional purposes. Citation of trade names does not constitute an official endorsement or approval of the use of such products. 